\title{
Fracture risk and associated factors in the elderly patients with ankylosing spondylitis
}

\author{
Yašlı ankilozan spondilitli hastalarda kırık riski ve ilișkili faktörler
}

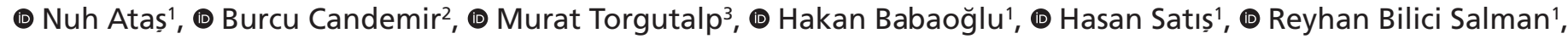

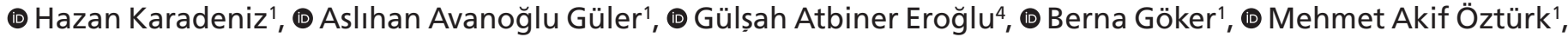

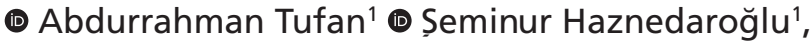

1 Gazi University Faculty of Medicine, Department of Internal Medicine, Division of Rheumatology, Ankara, Turkey

${ }^{2}$ Gazi University Faculty of Medicine, Department of Internal Medicine, Division of Geriatrics, Ankara, Turkey

${ }^{3}$ Ankara University Faculty of Medicine, Department of Internal Medicine, Division of Rheumatology, Ankara, Turkey

${ }^{4}$ Gazi University Faculty of Medicine, Department of Internal Medicine, Ankara, Turkey

\begin{abstract}
Objective: Osteopenia/osteoporosis and fractures are important health problems in ankylosing spondylitis (AS). Although these problems have been extensively investigated in young adult patients with AS, data are limited in the elderly patients. The aim of this study is to investigate the fracture risk and associated factors and frequency of low bone mineral density (BMD) in the elderly patients with AS.

Methods: We enrolled 20 elderly patients ( $\geq 65$ years) with AS and 21 age-sex matched controls. All patients fulfilled the modified New York criteria for AS. Dual-energy X-ray absorptiometry was used for the measurement of BMD and the Fracture Risk Assessment Tool for the calculation of fracture risk. Demographic data, clinical characteristics and radiographic features were recorded. Patients with conditions associated with secondary osteoporosis and those with a history of biologic agent use were excluded.

Results: The frequency of osteoporosis was 35\% in the elderly patients with $\mathrm{AS}$ and $4.8 \%$ in controls $(p=0.034)$. The frequency of low BMD (osteopenia and/or osteoporosis) was higher in patients with AS (14/20, $70 \%)$ than controls $(8 / 21,38 \%)$ at femoral neck $(p=0.041)$, while there was no significant difference at total hip and lumbar spine. The major osteoporotic and hip fracture risk were similar between the patients with AS and controls. C-reactive protein (CRP) was independently associated with both major osteoporotic [odds ratio (OR): 0.969; $95 \%$ confidence interval $(\mathrm{Cl}) 95 \% 0.61-1.32 ; \mathrm{p}=0.001]$ and hip (OR: 0.775; $95 \% \mathrm{Cl} 0.47-1.08 ; \mathrm{p}<0.001)$ fracture risks in the patients with AS.

Conclusion: Low BMD was more common in the elderly patients with AS compared to controls. High CRP was an independent predictor of 10-year fracture risk. Effective preventive strategies for fractures should be determined in the elderly AS patients with high CRP
\end{abstract}

Keywords: Ankylosing spondylitis, elderly, fracture risk, CRP, bone mineral density
Öz

Amaç: Osteopeni/osteoporoz ve kırıklar ankilozan spondilitte (AS) görülebilen önemli problemlerdir. Genç AS hastalarında bu problemler yoğun olarak çalıșılmıšken, yașlı AS hastalarında yeterli veri bulunmamaktadır. Bu çalıșmada, yașlı AS hastalarında kırık riski ve ilișkili faktörleri ve düșük kemik mineral yoğunluğu (KMY) sıkığını araștırdık.

Yöntem: Bu çalıșmaya 20 yașlı ( $\geq 65$ yaș) AS hastası ve 21 yaș/cinsiyet olarak eșleștirilmiș kontrol grubu dahil edildi. Bütün AS hastaları modifiye New York kriterlerini karșılamaktaydı. KMY ölçümü için çift $X$-ıșınlı absorpsiyometri, kırık riski hesaplanması için ise Kırık Riski Değerlendirme Aracı kullanıldı. Hastaların demografik, klinik ve radyografik özellikleri değerlendirildi.

Bulgular: Osteoporoz oranı yașlı AS hastalarında \%35, kontrol grubunda ise $\% 4,8$ idi $(p=0,034)$. Düșük KMY (osteopeni ve/veya osteoporoz) oranı AS hastalarında (14/20, \%70) femur boyun bölgesinde, kontrol grubuna (8/21, \%38) göre daha yüksek iken $(p=0,041)$, lomber vertebra ve total kalça ölçümlerinde anlamlı fark görülmedi. Majör osteoporotik ve kalça kırık riski her iki grupta da benzer idi. C-reaktif protein (CRP), yașlı AS hastalarında hem majör osteoporotik [odds oranı (OR): 0,969; \%95 güven aralığı (GA) 0,611,32; $p=0,001]$ hem de kalça kırık riski (OR: 0,775; \%95 GA 0,47$1,08 ; p<0,001)$ için bağımsız bir risk faktörüydü.

Sonuç: Düșük KMY yașlı AS hastalarında kontrollere göre daha sıktı. CRP, 10 yıllık kırık riskinin bağımsız bir risk faktörü olup, yüksek CRP'li yașlı AS hastalarında kırıklar için etkin önleyici stratejilerin geliștirilmesi gereklidir.

Anahtar Kelimeler: Ankilozan spondilit, yașlıık, kırık riski, CRP, kemik mineral dansitesi

İletișim / Correspondence:

Nuh Ataș MD, Gazi University Faculty of Medicine, Department of Internal Medicine, Division of Rheumatology, Ankara, Turkey

Tel.: +90 4162161015 E-posta: nuh_atas@yahoo.com ORCID ID: orcid.org/0000-0001-5880-4974

Geliș Tarihi/Received: 11.04.2021 Kabul Tarihi/Accepted: 22.06.2021

Atıf / Cite this article as: Ataș N, Candemir B, Torgutalp M, Babaoğlu H, Satıs H, Bilici Salman R, Karadeniz H, Avanoğlu Güler A, Atbiner Eroğlu G, Göker B,

Öztürk MA, Tufan A, Haznedaroğlu Ș. Fracture risk and associated factors in the elderly patients with ankylosing spondylitis. Ulus Romatol Derg 2021;13(2):59-65

๑Telif Hakkı 2021 Türkiye Romatoloji Derneği, Ulusal Romatoloji Dergisi, Galenos Yayınevi tarafından yayınlanmıștır.

${ }^{\odot}$ Copyright 2021 by the Turkish Society for Rheumatology / Journal of Turkish Society for Rheumatology published by Galenos Publishing House. 


\section{Introduction}

Ankylosing spondylitis (AS) is a potentially disabling, chronic inflammatory disease of the spine and sacroiliac joints, usually presenting with inflammatory back pain. [1] The onset of signs and symptoms are generally in the third decade of life and men are more commonly affected. ${ }^{[2,3]}$ In progressive disease, the fusion of spine, which results in bamboo spine, can be observed. AS has many comorbid diseases and extraarticular manifestations including psoriasis, uveitis, inflammatory bowel disease, ischemic heart disease, conduction defects and amyloidosis. ${ }^{[4]}$ In addition, osteoporosis and increased fracture risk are other two conditions which are frequently observed in AS. ${ }^{[5-7]}$

Osteoporosis is a skeletal disease characterized by low bone mass, microarchitectural deterioration, decreased skeletal strength and increased risk of fractures. ${ }^{[8]}$ The diagnosis of osteoporosis is based on bone mineral density (BMD) which is measured by dual-energy X-ray absorptiometry (DEXA). ${ }^{[9]}$ Previous studies showed a significantly increased risk of vertebral fractures in AS, whereas the increase in risk of hip fracture was not significant. ${ }^{[10-12]}$ Low BMD and osteoporosis which may be due to chronic inflammatory process are the main determinants of bone fragility, but their precise role on fracture risk in AS still needs to be established.

All fractures are burdensome associated with pain, disability, decrease in quality of life, physical and social function, need for assistance care and high financial cost. ${ }^{[13,14]}$ Fractures may lead to many complications according to their location. Vertebral fractures may lead to hyperkyphosis, severe neurologic complications and mortality in patients with AS. ${ }^{[15,16]}$ Hip fractures generally require hospitalization and are associated with increased mortality. ${ }^{[17]}$ Therefore, the evaluation of fracture risk in AS will improve the management of the disease. The Fracture Risk Assessment Tool (FRAX) has been developed to calculate fracture risk of patients. Fractures are more challenging for the elderly population due to age-related problems and increased comorbidities. Although AS is more prevalent in young populations, AS becomes an important health issue in the elderly population with better management and increase in the aging population. To the best of our knowledge, studies evaluating the fracture risk in the elderly patients with AS were not published previously. In this study, we aimed to investigate the fracture risk which was predicted by FRAX tool and associated factors in the elderly patients with AS.

\section{Materials and Methods}

\section{Patients and Study Design}

We retrospectively reviewed the medical records of patients with AS who were followed at the outpatient tertiary rheumatology clinic between January 2016 and January 2020. Inclusion criteria were fulfilling the New York criteria for AS, ${ }^{[18]}$ the presence of DEXA measurement of BMD for total hip, femoral neck and lumbar spine, and being $\geq 65$ years of age at the time DEXA scanning. History of fragility fracture, previous treatment with biologic agents and bisphosphonates prior to DEXA measurement, hyperparathyroidism, diabetes mellitus, chronic renal diseases (glomerular filtration rate $<60 \mathrm{~mL} / \mathrm{min} / 1.73 \mathrm{~m}^{2}$ or renal damage longer than 3 months), a previous history of glucocorticoid treatment (equivalent of $\geq 5 \mathrm{mg} /$ day prednisolone) longer than 3 months prior to DEXA or use of any dose glucocorticoid at the time of DEXA scanning, having any comorbidity which was defined in FRAX tool as a risk factor of secondary osteoporosis including osteogenesis imperfecta, hyperthyroidism, hypogonadism, premature menopause ( $<45$ years), chronic malabsorption or malnutrition and chronic liver disease were exclusion criteria. Twenty patients with AS were eligible for our study. We recruited 21 suitable consecutive controls that applied the outpatient geriatric clinics, and all of them had DEXA scanning of total hip, femoral neck and lumbar spine and none of them had any comorbidity leading to secondary osteoporosis.

Demographic, clinical and laboratory characteristics of patients, including gender, age, smoking status, alcohol consumption, time from diagnosis, medications, comorbidities, HLA B27 status, vitamin D, creatinine and alanine aminotransferase levels at the same day or in the previous 1 month (if which one is available) of DEXA scanning, were recorded. We also recorded the median scores of Bath Ankylosing Spondylitis Disease Activity index (BASDAI), Bath Ankylosing Spondylitis Disease Functional index (BASFI), Bath Ankylosing Spondylitis Disease Metrological index (BASMI) and median levels of erythrocyte sedimentation ratio (ESR) and C-reactive protein (CRP) in the previous one year of DEXA scanning. If patients had any infection, the concomitant CRP and ESR tests were excluded. This study was approved by Gazi University Ethical Committee (approval no: 2019-280), and it was conducted in accordance with the 1975 Helsinki Declaration. Informed consent was obtained from all participants.

\section{Radiological Assessment}

Bilateral cervical and lumbar radiographs were used for the evaluation of syndesmophytes and calculation of the modified Stoke Ankylosing Spondylitis Spinal score (mSASSS). Sacroiliitis sum score (SSS) (range 0-8) was calculated as the sum of the left and right sacroiliac joint grades on plain radiographs in accordance with the 
modified New York criteria. ${ }^{[18]}$ The time difference between radiographs and DEXA scanning was ranged from 1 to 9 months.

\section{Measurements of BMD and Fracture Risk Assessment}

BMD of total hip, femoral neck and lumbar spine (anterior-posterior, L1-L4) were measured using DEXA scanner. All measurements were performed on two machines which had the same brand (Hologic Horizon WI Bone Densitometer, USA). T-score and/or $\mathrm{g} / \mathrm{cm}^{2}$ were used for the expression of BMD. The World Health Organization diagnostic criteria were used for the definition of normal BMD (T-score $\geq-1$ standard deviation), osteopenia $(-2.5<$ T-score <-1.0) and osteoporosis (T-score $\leq-2.5) .{ }^{[19,20]}$ The T-score was derived using the Third National Health and Nutrition Examination Study (NHANES III) data. ${ }^{[21]}$ We defined low BMD as a T-score $\leq-1.0$, which includes both osteopenia and osteoporosis.

The FRAX is an internet based tool (available from: http://www.shef.ac.uk/FRAX) that calculates the 10-year probabilities of major osteoporotic fracture (hip, clinical vertebral, wrist or humerus) and hip fracture. FRAX score is calculated from following risk factors; age, sex, body mass index (BMI), previous fragility fracture, current smoking status, history of parental hip fracture, alcohol use, glucocorticoid use, rheumatoid arthritis, secondary osteoporosis (type I diabetes, osteogenesis imperfecta, untreated long-standing hyperthyroidism, premature menopause, hypogonadism, malabsorption, chronic malnutrition and chronic liver disease). The femoral neck is the only validated skeletal region for use with FRAX and can be used optionally in FRAX to increase fracture risk prediction. ${ }^{[22]}$ A Turkish FRAX model is currently available. In our study, FRAX tool was used for the calculation of probability of osteoporotic fracture. BMD of femoral neck which was expressed as T-score was also used in FRAX.

\section{Statistical Analysis}

The numerical variables were investigated by using visual (histograms, probability plots) and analytical methods (Shapiro-Wilk's test) for evaluating the normality of distribution. Categorical variables were presented as numbers and percentages, and continuous variables were presented with mean \pm standard deviation or median [interquartile range (IQR)] according to their normality distribution, respectively. The chi-square test or Fisher's Exact test, where appropriate, was used to compare categorical variables in different groups. Group comparisons for continuous variables were performed by the Student's t-test or Mann-Whitney $U$ tests according to normality distribution. The Pearson/Spearman correlation coefficients were used to determine the relationship between variables that potentially affected hip and major osteoporotic fracture risks. In the multiple linear regression models, in which the predictor factors for hip and major osteoporotic fracture risks were assessed, sacroiliac sum score, CRP, and BASFI were used as independent factors according to the results of univariate analyses. The analyses were performed in SPSS version 15 (IBM, SPSS, Chicago, IL, USA) software and the statistical significance level was considered to be less than 0.05 for analyses.

\section{Results}

In this study, 20 elderly patients with AS (8 females and 12 males) and 21 control subjects (7 females and 14 males) were included. Age, sex, educational status, BMI and smoking habits were similar between two groups ( $p>0.05$, Table 1). The median (IQR) time from diagnosis was 27 (21-34) years. Two patients had a history of parenteral hip fracture and 6 subjects from both patient group and control group had hypertension.

The median (IQR) BASDAI, BASFI and BASMI scores were 3.3 (2.3-5.3), 3.1 (2-4.2), 5.4 (4-6.4), respectively. Seventeen $(85 \%)$ patients were HLA B27 positive. Sixteen patients $(70 \%)$ had syndesmophytes and the median (IQR) mSASSS score was 30 (14-43). The median (IQR) CRP level was above normal range, $6 \mathrm{mg} / \mathrm{L}(0-5 \mathrm{mg} / \mathrm{L})$. The median (IQR) vitamin D levels of patients and control subjects were $21.5(14.5-29) \mathrm{ng} / \mathrm{mL}$ and $20(16-28) \mathrm{ng} / \mathrm{mL}$, respectively (Table 1). Among the patients with AS, 15 of them had a vitamin D level $<30 \mathrm{ng} / \mathrm{mL}$. All patients were treated with on demand non-steroidal antiinflammatory drugs and 6 of them received sulfasalazine treatment.

At all sites, the ratio of low BMD (osteopenia/ osteoporosis) was more common in patients with AS, but the only statistically significant difference of low BMD between patients and controls was at femoral neck (Table 2). The ratio of total osteoporosis (a T-score $\leq-2.5$ standard deviation at either the total hip, femoral neck or lumbar spine) was $35 \%$ in the patients with AS and $4.8 \%$ in the control group ( $\mathrm{p}=0.034)$. In the patients with AS, the ratios of osteoporosis for lumbar spine, femoral neck and total hip were $25 \%, 20 \%$ and $10 \%$, respectively. The BMD $\left(\mathrm{g} / \mathrm{cm}^{2}\right)$ of lumbar spine, total hip and femoral neck was positively correlated with BMI $[(\mathrm{r}=0.649, \mathrm{p}=0.002),(\mathrm{r}=0.731, \mathrm{p}<0.001)$ and $(\mathrm{r}=0.548, \mathrm{p}=0.012)$, respectively]. When we compared patients with and without syndesmophytes, the median (IQR) lumbar spinal BMD was $1.001(0.926-1.146) \mathrm{g} / \mathrm{cm}^{2}$ vs $0.807(0.764-0.842) \mathrm{g} / \mathrm{cm}^{2},(\mathrm{p}=0.006)$ and the median (IQR) 
Table 1. Demographic and clinical characteristics of patients with ankylosing spondylitis (AS) and control subjects

\begin{tabular}{|c|c|c|c|}
\hline & $\begin{array}{c}\text { Patients with } \\
\text { AS } \\
(n=20)\end{array}$ & $\begin{array}{c}\text { Control } \\
\text { subjects } \\
(n=21)\end{array}$ & p-value \\
\hline Sex, male & $12(60)$ & $14(66.7)$ & 0.66 \\
\hline Age, years & $66(65-69)$ & $68(65-73)$ & 0.12 \\
\hline BMI $\left(\mathrm{kg} / \mathrm{m}^{2}\right)$, mean $\pm \mathrm{SD}$ & $26.4 \pm 4.7$ & $27.8 \pm 3.5$ & 0.28 \\
\hline \multicolumn{4}{|l|}{ Educational status } \\
\hline $4-8$ years & $5(25)$ & $2(9.5)$ & 0.38 \\
\hline 8-12 years & $9(45)$ & $10(47.6)$ & \\
\hline $12-16$ years & $6(30)$ & $9(42.9)$ & \\
\hline Smoking & $6(30)$ & $4(19)$ & 0.33 \\
\hline Family history of fracture & $2(10)$ & $0(0)$ & 0.23 \\
\hline Vitamin D levels (ng/mL) & $21.5(14.5-29)$ & $20(16-28)$ & 0.98 \\
\hline ALT (U/L) & $\begin{array}{c}17.5 \\
(10.5-20.5)\end{array}$ & $\begin{array}{c}16 \\
(14-18.5)\end{array}$ & 0.91 \\
\hline Creatinine (mg/dL) & $0.82 \pm 0.19$ & $0.83 \pm 0.16$ & 0.73 \\
\hline Time from diagnosis (years) & $27(21-34)$ & - & - \\
\hline $\begin{array}{l}\text { Sacroiliitis sum score, median } \\
\text { (min-max) }\end{array}$ & $6(5-8)$ & - & - \\
\hline Presence of syndesmophyte & $14(70)$ & - & - \\
\hline mSASSS & $30(14-43)$ & - & - \\
\hline HLAB27 positivity & $17(85)$ & - & - \\
\hline BASDAI & $3.3(2.3-5.3)$ & - & - \\
\hline BASFI & $3.1(2-4.2)$ & - & - \\
\hline BASMI & $5.4(4-6.4)$ & - & - \\
\hline $\operatorname{ESR}(\mathrm{mm} / \mathrm{h})$ & $27.5(13-36)$ & - & - \\
\hline CRP (mg/L) & $6(2.3-8.7)$ & - & - \\
\hline \multicolumn{4}{|l|}{ Medication } \\
\hline NSAID, $\mathrm{n}$ & 20 & & \\
\hline Sulphasalazine, n & 6 & & \\
\hline \multicolumn{4}{|c|}{$\begin{array}{l}\text { Values given as median (interquartile range) or number (percentage), unless stated. } \\
\text { p<0.05 was considered statistically significant. ALT: Alanine aminotransferase, } \\
\text { BASDAl: Bath Ankylosing Spondylitis Disease Activity index, BASFl: Bath Ankylosing } \\
\text { Spondylitis Disease Functional index, BASMI: Bath Ankylosing Spondylitis } \\
\text { Disease Metrological index, BMI: Body mass index, CRP: C-reactive protein, ESR: } \\
\text { Erythrocyte sedimentation rate, Min: Minimum, Max: Maximum, mSASSS: Modified } \\
\text { Stoke Ankylosing Spondylitis Spinal score, NSAID: Non-steroidal antiinflammatory } \\
\text { drugs }\end{array}$} \\
\hline
\end{tabular}

lumbar spinal $\mathrm{T}$-score was -0.850 (-1.475 to 0.500$)$ vs -2.25 $(-2.55$ to -1.59$),(\mathrm{p}=0.019)$, respectively.

In the Spearman's correlation analysis, 10-year probability of hip fracture risk was negatively correlated with BMI ( $\mathrm{r}=-0.465, \mathrm{p}=0.039)$ and positively correlated with CRP ( $\mathrm{r}=0.639, \mathrm{p}=0.002)$ and SSS $(\mathrm{r}=0.554, \mathrm{p}<0.011)$. Ten year probability of major osteoporotic fracture was negatively correlated with $\mathrm{BMI}(\mathrm{r}=-0.698, \mathrm{p}=0.001)$ and positively correlated with BASFI $(\mathrm{r}=0446, \mathrm{p}=<0.049)$ and CRP ( $\mathrm{r}=0.871, \mathrm{p}<0.001)$ (Table 3). BASDAI was fairly correlated with 10-year probability of major osteoporotic fracture, but this correlation was not statistically significant. In the multiple linear regression analysis, only CRP was significantly associated with 10 -year probability of major
Table 2. Comparison of bone mineral density and fracture risk between patients with ankylosing spondylitis (AS) and control subjects

\begin{tabular}{|c|c|c|c|}
\hline & $\begin{array}{l}\text { Patients } \\
\text { with AS } \\
(n=20)\end{array}$ & $\begin{array}{l}\text { Control } \\
\text { subjects } \\
(n=21)\end{array}$ & p-value \\
\hline \multicolumn{4}{|l|}{ Total hip T-score } \\
\hline Low $\mathrm{BMD}^{+}, \mathrm{n}(\%)$ & $9(45)$ & $4(19)$ & 0.074 \\
\hline \multicolumn{4}{|l|}{ Femoral neck T-score } \\
\hline Low BMD ${ }^{+}, \mathrm{n}(\%)$ & $14(70)$ & $8(38)$ & 0.041 \\
\hline \multicolumn{4}{|l|}{ Lumbar spine T-score } \\
\hline Low $\mathrm{BMD}^{+}, \mathrm{n}(\%)$ & $11(55)$ & $7(33)$ & 0.162 \\
\hline $\begin{array}{l}\text { 10-year probability of major } \\
\text { osteoporotic fracture, median } \\
\text { (IQR) }\end{array}$ & $4.3(3.2-10.2)$ & $3.4(2.8-4.7)$ & 0.095 \\
\hline $\begin{array}{l}\text { 10-year probability of hip fracture, } \\
\text { median (IQR) }\end{array}$ & $\begin{array}{c}1.3 \\
(0.65-2.65)\end{array}$ & $\begin{array}{c}0.8 \\
(0.5-1)\end{array}$ & 0.097 \\
\hline \multicolumn{4}{|c|}{$\begin{array}{l}\text { p<0.05 was considered statistically significant. BMD: Bone mineral density, IQR: } \\
\text { Interquartile range }\end{array}$} \\
\hline \multicolumn{4}{|c|}{ 'Low BMD includes osteopenia and/or osteoporosis } \\
\hline
\end{tabular}

Table 3. Correlations of parameters with 10-year probability of hip and major osteoporotic fracture

\begin{tabular}{|c|c|c|c|c|}
\hline & \multicolumn{2}{|c|}{$\begin{array}{c}\text { 10-year probability of } \\
\text { hip fracture }\end{array}$} & \multicolumn{2}{|c|}{$\begin{array}{l}\text { 10-year } \\
\text { probability } \\
\text { of major } \\
\text { osteoporotic } \\
\text { fracture }\end{array}$} \\
\hline & $r$ & $p$-value & $r$ & $\mathrm{p}$-value \\
\hline Age & 0.256 & 0.276 & 0.180 & 0.448 \\
\hline Time from diagnosis & -0.217 & 0.358 & -0.394 & 0.085 \\
\hline BMI & -0.465 & 0.039 & -0.698 & 0.001 \\
\hline BASDAI & 0.223 & 0.345 & 0.411 & 0.072 \\
\hline BASFI & 0.230 & 0.329 & 0.446 & 0.049 \\
\hline BASMI & 0.317 & 0.173 & 0.172 & 0.469 \\
\hline mSASSS & 0.161 & 0.499 & 0.052 & 0.826 \\
\hline Sacroiliitis sum score & 0.554 & 0.011 & 0.292 & 0.212 \\
\hline ESR & 0.152 & 0.523 & 0.386 & 0.093 \\
\hline CRP & 0.639 & 0.002 & 0.775 & $<0.001$ \\
\hline Vitamin D & -0.217 & 0.358 & -0.097 & 0.685 \\
\hline \multicolumn{5}{|c|}{$\begin{array}{l}\text { p<0.05 was considered statistically significant. BASDAl: Bath Ankylosing Spondylitis } \\
\text { Disease Activity index, BASFl: Bath Ankylosing Spondylitis Disease Functional index, } \\
\text { BASMI: Bath Ankylosing Spondylitis Disease Metrological index, BMI: Body mass } \\
\text { index, CRP: C-reactive protein, ESR: Erythrocyte sedimentation rate, mSASSS: } \\
\text { Modified Stoke Ankylosing Spondylitis Spinal score }\end{array}$} \\
\hline
\end{tabular}

osteoporotic [odds ratio (OR): 0.969; 95\% confidence interval (CI) 95\% 0.61-1.32; $\mathrm{p}=0.001]$ and hip (OR: 0.775; 95\% CI 0.47-1.08; $\mathrm{p}<0.001$ ) fracture risks (Table 4).

\section{Discussion}

In this study, we investigated the low BMD, fracture risk and factors associated with fracture risk in the elderly patients with AS. To our knowledge, this is the first study which assessed the fracture risk by using FRAX tool in the elderly patients with AS.

The rate of low BMD between patients with AS and control group was different according to the site of DEXA 
Table 4. Variables associated with 10-year probability of major osteoporotic and hip fracture

\begin{tabular}{|c|c|c|c|c|c|c|}
\hline \multirow[t]{2}{*}{ Variables } & \multicolumn{3}{|c|}{$\begin{array}{l}\text { Major osteoporotic fracture } \\
\text { risk }^{\dagger}\end{array}$} & \multicolumn{3}{|c|}{ Hip fracture risk ${ }^{\ddagger}$} \\
\hline & OR & $95 \% \mathrm{Cl}$ & p-value & OR & $95 \% \mathrm{Cl}$ & p-value \\
\hline CRP & 0.969 & 0.61 to 1.32 & 0.001 & 0.775 & $\begin{array}{l}0.47 \text { to } \\
1.08\end{array}$ & $<0.001$ \\
\hline SSS & - & - & - & 0.398 & $\begin{array}{c}-0.60 \text { to } \\
1.40\end{array}$ & 0.413 \\
\hline BASFI & 0.325 & -0.56 to 1.21 & 0.448 & - & - & - \\
\hline \multicolumn{7}{|c|}{$\begin{array}{l}\text { p<0.05 was considered statistically significant. BASFI: Bath Ankylosing Spondylitis } \\
\text { Disease Functional index, Cl: Confidence interval, CRP: C-reactive protein, OR: Odds } \\
\text { ratio, SSS: Sacroilititis sum score }\end{array}$} \\
\hline \multicolumn{7}{|c|}{${ }^{+} R^{2}: 0.739$} \\
\hline${ }^{\ddagger} R^{2}: 0.639$ & & & & & & \\
\hline
\end{tabular}

scanning. At lumbar spine and total hip, there was no significant difference, while at femoral neck, patients with AS had a higher ratio of low BMD. The indifference of low BMD at lumbar spine may be related to structural features. Structural damage, such as periosteal bone formation and syndesmophytes, may affect DEXA measurements in the elderly patients with longstanding disease ${ }^{[23]}$ and as a result, a high BMD may be measured by DEXA in spite of the presence of low BMD. In our study, the higher scores of BMD in patients with syndesmophytes versus without syndesmophytes also support this hypothesis. Another factor may be related to technical factors. In a recent study, BMD of lumbar spine was compared between posterio-anterior (PA) and lateral projections of DEXA and lateral projection detected more patients with low BMD than PA projection. ${ }^{[24]}$ The similar proportion of low BMD at total hip between patients and controls may also be related to structural changes. In a study with a 5-year follow-up of patients with AS, BMD decreased at the femoral neck while increased at the total hip and lumbar spine both for lateral and AP projections. ${ }^{[25]}$ Hip joints are frequently involved extraaxial joints ${ }^{[26]}$ in AS and it may be postulated that arthritic changes in long-term disease may interfere with DEXA measurement of total hip. When we take into account the high structural damage in the elderly AS patients with longstanding disease, DEXA assessment of femoral neck may be better for the evaluation of BMD.

The frequency of osteoporosis has been frequently investigated in non-geriatric patients with AS. In a recent meta-analysis, the range of total osteoporosis (hip and/ or spinal), femoral neck and lumbar spine osteoporosis in patients with AS (range of mean age; 28 to 52 years) was $11.7-34.4 \%, 6.4-16.8 \%$ and $11.6-19.1 \%$, respectively. In our study, the ratio of total osteoporosis (hip and/or spinal) was similar with the highest value of the range, while the ratio of femoral neck and spinal osteoporosis was higher than the ranges in their counterpart sites of this meta-analysis.
In addition, steroid use and comorbidities such as chronic liver disease, kidney disease and inflammatory bowel disease, which are important risk factors for osteoporosis, had been reported in many studies of this meta-analysis. ${ }^{[27]}$ Vitamin D deficiency was also high (range: $26 \%$ to $76 \%$ ) as in our study. We observed that both patients with AS and controls had low vitamin D levels, which may have important effects on bone health. Therefore, vitamin D levels should be checked regularly and appropriate supplementation should be given in the elderly patients with AS.

The 10-year major osteoporotic and hip fracture risk were higher in patients with AS, but it was not statistically significant. In the elderly patients with AS, major osteoporotic fracture risk was correlated with BASFI, BMI and CRP, while hip fracture risk was correlated with CRP, $\mathrm{BMI}$ and SSS. In the multilinear regression analysis, CRP was the only parameter that was associated with both major osteoporotic and hip fracture risk.

There are controversial data about the impact of BMI on fracture risk. Traditionally, low BMI has been recognized as an important risk factor for fragility fracture. This increased risk may be related to many factors including low BMD, increased fall risk due to muscle weakness and decreased soft tissue that protect bones from impact forces. ${ }^{[28]}$ In early studies high BMI was protective against fragility fracture, ${ }^{[29-31]}$ but more recent studies suggest that higher BMI may be a significant risk factor for fracture, especially at locations other than hip. ${ }^{[32-34]}$ In another study that investigated the effect of BMI on fracture risk, no direct effect of BMI on fracture risk was observed. The association between fracture risk and BMI was largely mediated by femoral neck BMD in both genders and without BMD, the contribution of BMI to fracture prediction was low. ${ }^{[35]}$ In our study, BMI was positively correlated with BMD of all sites including femoral neck, but in multivariate analysis, there was no significant association between BMI and 10-year major osteoporotic and hip fracture risk.

$\mathrm{CRP}$ is an acute phase reactant that increases during systemic inflammation. CRP has a good correlation with BMD. ${ }^{[3,37]}$ Under inflammatory conditions, IL- 6 and tumor necrosis factor alpha related osteoclastogenesis may lead to generalized osteoporosis. ${ }^{[38]}$ In our study, high CRP was significantly associated with both major osteoporotic fracture and hip fracture risk. This significant association shows the important impact of ongoing systemic inflammation on fracture risk. Therefore, the elderly AS patients with high CRP should be followed carefully for fracture risk and if patients are also clinically active in addition to high CRP, by considering risk-benefit ratio, more intensive treatment may be postulated to decrease fracture risk in this age group. 
Sacroiliitis also has an effect on BMD and fracture risk. Severity of sacroiliitis was associated with major osteoporotic and hip fracture risk in axSpA patients with low BMD. ${ }^{[39,40]}$ Sacroiliitis reflects the cumulative inflammation of disease. In our study, we used SSS which scores the severity of radiographic sacroiliitis. In correlation analysis, SSS was correlated with hip fracture risk, but in multivariate analysis, SSS was not significantly associated with hip fracture.

\section{Study Limitations}

Our study has some limitations. The number of patients was relatively low. There are many reasons for low number of patients. First, the prevalence of AS is highest at the ages of 30-39 years and the prevalence decreases with age; therefore, the elderly patients with AS constitute a small proportion of AS cases. ${ }^{[41]}$ Second, AS patients had a long duration of disease and some of them had used corticosteroids (mostly due to misdiagnosis of other rheumatologic disease such as rheumatoid arthritis) and biologic agents were excluded from the study. Third, when we consider the advanced age of patients, some of them had comorbid diseases that might affect BMD and were also excluded. Another limitation is related to FRAX tool. Although FRAX includes RA as a risk factor in the calculation of fracture risk, AS is not included in the calculation. The prevalence of osteoporosis in AS seems to be high; therefore, FRAX may underestimate the fracture risk in AS. In addition, the time from diagnosis was negatively correlated with the risk of fracture risk, this situation may be related to the exclusion of patients with fractures, who might have a longer duration of diagnosis.

\section{Conclusion}

The prevalence of low BMD was high among the elderly patients with AS and high CRP levels were a significant risk factor for both major osteoporotic and hip fractures. We recommend further research for the definition of other risk factors for osteoporosis and osteoporotic fractures and improvement of strategies for fracture prevention in the elderly AS patients with high CRP.

\section{Ethics}

Ethics Committee Approval: This study was approved by Gazi University Ethical Committee (approval no: 2019280), and it was conducted in accordance with the 1975 Helsinki Declaration.

Informed Consent: Informed consent was obtained from all participants.

Peer-review: Externally peer-reviewed.

\section{Authorship Contributions}

Concept: N.A., Ş.H., Design: N.A., Ş.H., Data Collection or Processing: N.A., B.C., M.T., H.B., H.S.,
R.B.S., H.K., A.A.G., G.A.E., B.G., M.A.Ö., A.T., Ş.H., Analysis or Interpretation: N.A., B.C., M.T., H.B., H.S., R.B.S., H.K., A.A.G., G.A.E., B.G., M.A.Ö., A.T., S..H., Literature Search: N.A., B.C., M.T., H.B., H.S., R.B.S., H.K., A.A.G., G.A.E., B.G., M.A.Ö., A.T., S.H., Writing: N.A., B.C., M.T., H.B., H.S., R.B.S., H.K., A.A.G., G.A.E., B.G., M.A.Ö., A.T., Ş.H.

Conflict of Interests: No conflict of interests was declared by the authors.

Financial Disclosure: The authors declared that this study received no financial support.

\section{References}

1. Sieper J, Appel H, Braun J, Rudwaleit M. Critical appraisal of assessment of structural damage in ankylosing spondylitis: implications for treatment outcomes. Arthritis Rheum 2008;58:649-56.

2. Feldtkeller E, Khan MA, van der Heijde D, van der Linden S, Braun J. Age at disease onset and diagnosis delay in HLA-B27 negative vs. positive patients with ankylosing spondylitis. Rheumatol Int 2003;23:61-6.

3. Braun J, Bollow M, Remlinger G, et al. Prevalence of spondylarthropathies in HLA-B27 positive and negative blood donors. Arthritis Rheum 1998;41:58-67.

4. Stolwijk C, van Tubergen A, Castillo-Ortiz JD, Boonen A. Prevalence of extra-articular manifestations in patients with ankylosing spondylitis: a systematic review and meta-analysis. Ann Rheum Dis 2015;74:65-73.

5. Davey-Ranasinghe N, Deodhar A. Osteoporosis and vertebral fractures in ankylosing spondylitis. Curr Opin Rheumatol 2013;25:509-16.

6. van der Weijden MA, Claushuis TA, Nazari T, et al. High prevalence of low bone mineral density in patients within 10 years of onset of ankylosing spondylitis: a systematic review. Clin Rheumatol 2012;31:1529-35.

7. Moltó A, Etcheto A, van der Heijde D, et al. Prevalence of comorbidities and evaluation of their screening in spondyloarthritis: results of the international cross-sectional ASAS-COMOSPA study. Ann Rheum Dis 2016;75:1016-23.

8. NIH Consensus Development Panel on Osteoporosis Prevention, Diagnosis, and Therapy. Osteoporosis prevention, diagnosis, and therapy. JAMA 2001;285:785-95.

9. Cummings SR, Bates D, Black DM. Clinical use of bone densitometry: scientific review. JAMA 2002;288:1889-97.

10. van der Weijden MA, van der Horst-Bruinsma IE, van Denderen JC, et al. High frequency of vertebral fractures in early spondylarthropathies. Osteoporos Int 2012;23:1683-90.

11. Jun JB, Joo KB, Her MY, Kim TH, Bae SC, Yoo DH, Kim SK. Femoral bone mineral density is associated with vertebral fractures in patients with ankylosing spondylitis: a cross-sectional study. J Rheumatol 2006;33:1637-41.

12. Vosse D, Landewé R, van der Heijde D, van der Linden S, van Staa TP, Geusens P. Ankylosing spondylitis and the risk of fracture: results from a large primary care-based nested case-control study. Ann Rheum Dis 2009;68:1839-42. 
13. Harvey N, Dennison E, Cooper C. Osteoporosis: impact on health and economics. Nat Rev Rheumatol 2010;6:99-105.

14. Feldtkeller E, Vosse D, Geusens P, van der Linden S. Prevalence and annual incidence of vertebral fractures in patients with ankylosing spondylitis. Rheumatol Int 2006;26:234-9.

15. Vosse D, van der Heijde D, Landewé R, et al. Determinants of hyperkyphosis in patients with ankylosing spondylitis. Ann Rheum Dis 2006;65:770-4.

16. Schiefer TK, Milligan BD, Bracken CD, et al. In-hospital neurologic deterioration following fractures of the ankylosed spine: a single-institution experience. World Neurosurg 2015;83:775-83.

17. Hallberg I, Bachrach-Lindström M, Hammerby S, Toss G, Ek AC. Health-related quality of life after vertebral or hip fracture: a sevenyear follow-up study. BMC Musculoskelet Disord 2009;10:135.

18. van der Linden S, Valkenburg HA, Cats A. Evaluation of diagnostic criteria for ankylosing spondylitis. A proposal for modification of the New York criteria. Arthritis Rheum 1984;27:361-8.

19. Kanis JA, Melton LJ 3rd, Christiansen C, Johnston CC, Khaltaev N. The diagnosis of osteoporosis. J Bone Miner Res 1994;9:1137-1141.

20. No authors listed. Assessment of fracture risk and its application to screening for postmenopausal osteoporosis. Report of a WHO Study Group. World Health Organ Tech Rep Ser 1994;843:1-129.

21. Looker AC, Wahner HW, Dunn WL, et al. Updated data on proximal femur bone mineral levels of US adults. Osteoporos Int 1998;8:468-89.

22. Kanis JA, Oden A, Johnell O, et al. The use of clinical risk factors enhances the performance of $\mathrm{BMD}$ in the prediction of hip and osteoporotic fractures in men and women. Osteoporos Int 2007;18:1033-46.

23. Sambrook PN, Geusens P. The epidemiology of osteoporosis and fractures in ankylosing spondylitis. Ther Adv Musculoskelet Dis 2012;4:287-92.

24. Fitzgerald G, Anachebe T, McCarroll K, O'Shea F. Measuring bone density in axial spondyloarthropathy: Time to turn things on their side? Int J Rheum Dis 2020;23:358-66.

25. Deminger A, Klingberg E, Lorentzon M, et al. Which measuring site in ankylosing spondylitis is best to detect bone loss and what predicts the decline: results from a 5-year prospective study. Arthritis Res Ther 2017;19:273

26. Sampaio-Barros PD, Bertolo MB, Kraemer MH, Neto JF, Samara AM. Primary ankylosing spondylitis: patterns of disease in a Brazilian population of 147 patients. J Rheumatol 2001;28:560-5.

27. Ramírez J, Nieto-González JC, Curbelo Rodríguez R, Castañeda S, Carmona L. Prevalence and risk factors for osteoporosis and fractures in axial spondyloarthritis: a systematic review and meta-analysis. Semin Arthritis Rheum 2018;48:44-52.

28. Nielson CM, Srikanth P, Orwoll ES. Obesity and fracture in men and women: an epidemiologic perspective. J Bone Miner Res 2012;27:1-10.

29. Johnell O, Gullberg B, Kanis JA, et al. Risk factors for hip fracture in European women: the MEDOS Study. Mediterranean Osteoporosis Study. J Bone Miner Res 1995;10:1802-15.

30. Joakimsen RM, Fønnebø V, Magnus JH, Tollan A, Søgaard AJ. The Tromsø Study: body height, body mass index and fractures. Osteoporos Int 1998;8:436-42.

31. Kanis J, Johnell O, Gullberg B, et al. Risk factors for hip fracture in men from southern Europe: the MEDOS study. Mediterranean Osteoporosis Study. Osteoporos Int 1999;9:45-54.

32. Compston JE, Watts NB, Chapurlat R, et al; Glow Investigators. Obesity is not protective against fracture in postmenopausal women: GLOW. Am J Med 2011;124:1043-50.

33. Nielson CM, Marshall LM, Adams AL, et al; Osteoporotic Fractures in Men Study Research Group. BMI and fracture risk in older men: the osteoporotic fractures in men study (MrOS). J Bone Miner Res 2011;26:496-502.

34. Pirro M, Fabbriciani G, Leli C, et al. High weight or body mass index increase the risk of vertebral fractures in postmenopausal osteoporotic women. J Bone Miner Metab 2010;28:88-93.

35. Chan MY, Frost SA, Center JR, Eisman JA, Nguyen TV. Relationship between body mass index and fracture risk is mediated by bone mineral density. J Bone Miner Res 2014;29:2327-35.

36. Ghozlani I, Ghazi M, Nouijai A, et al. Prevalence and risk factors of osteoporosis and vertebral fractures in patients with ankylosing spondylitis. Bone 2009;44:772-6.

37. Klingberg E, Lorentzon M, Mellström D, et al. Osteoporosis in ankylosing spondylitis - prevalence, risk factors and methods of assessment. Arthritis Res Ther 2012;14:R108. doi: 10.1186/ar3833.

38. Redlich K, Smolen JS. Inflammatory bone loss: pathogenesis and therapeutic intervention. Nat Rev Drug Discov 2012;11:234-50.

39. Kang KY, Kwok SK, Ju JH, Hong YS, Park SH. Assessment of fracture risk in patients with axial spondyloarthritis: a case-control study using the fifth Korean National Health and Nutrition Examination Survey (KNHANES V). Scand J Rheumatol 2016;45:23-31.

40. Kim HN, Jung JY, Hong YS, Park SH, Kang KY. Severe bone marrow edema on sacroiliac joint MRI increases the risk of low BMD in patients with axial spondyloarthritis. Sci Rep 2016;6:22158. doi: $10.1038 /$ srep22158.

41. Park JS, Hong JY, Park YS, Han K, Suh SW. Trends in the prevalence and incidence of ankylosing spondylitis in South Korea, 20102015 and estimated differences according to income status. Sci Rep 2018;8:7694. 